\title{
Serine protease activity in boar seminal vesicles and its immunological similarity to sperm acrosin
}

\author{
D. Čechová ${ }^{1}$, V. Jonáková ${ }^{1 *}, \mathrm{~L}$. Veselský $^{1}$ and \\ E. Töpfer-Petersen ${ }^{2 \dagger}$ \\ ${ }^{1}$ Institute of Molecular Genetics, Czech Academy of Sciences of the Czech Republic, \\ Flemingovo nam. 2, 16637 Prague 6, Czech Republic; and ${ }^{2}$ Andrology Unit, University of \\ Munich, D-8000 Munich 2, Germany
}

\begin{abstract}
A mouse monoclonal antibody against boar acrosin and antiserum prepared to highly purified acrosin in female rabbits were used to detect the antigen in various fluids and tissues of boars using an indirect immunofluorescence technique. A strong reaction was found in fluid and epithelial tissue of the seminal vesicles as well as in the germinal cells in the testis. No immunoreactivity was detected in tissues of the epididymides and other organs of the boar. The antigens present in seminal vesicle fluid of boars were partially purified by column chromatography. It was demonstrated that two antigens differing in molecular mass were present and both possessed protease and amidase activity. The higher molecular mass antigen eluted from a gel filtration column in a volume identical to that of proacrosin. The same result was obtained in polyacrylamide gel electrophoresis in sodium dodecyl sulfate (SDS-PAGE). The low molecular mass antigen was eluted from Sephadex G-75 column together with natural protease inhibitors corresponding in molecular mass to less than $20 \mathrm{kDa}$. The mobility of the antigen in SDS-PAGE was greater than that of chymotrypsin. It is assumed that the protease from seminal vesicle epithelia resembled acrosin in structure and function. Acrosin may therefore not be specific for spermatozoa.
\end{abstract}

\section{Introduction}

Acrosin is one of the hydrolases released from the sperm acrosome as a result of the acrosomal reaction and is considered to play an essential role in fertilization, in recognition, binding and penetration of the zona pellucida of the ovum (for review, see Klemm et al., 1991), and in cleavage of fibronectins and other proteins of basal membranes (Planchenaut et al., 1991). Acrosin is initially present in the acrosome as a zymogen, proacrosin, (for review see Parrish and Polakoski, 1979), the activation of which takes place after acrosome disruption (Brown and Harrison, 1978). The localization of the site of acrosin synthesis has been the subject of intensive research. Proacrosin-acrosin is found exclusively within the acrosome of mammalian spermatozoa synthesized postmeiotically in round spermatids (Flörke et al., 1983). The proacrosin gene is expressed only in the testes, and all other tissues assayed were found to possess neither immunoreactivity against antibodies to acrosin nor features of proacrosin expression (Nayernia et al., 1992). The seminal vesicle fluid and tissues have not been tested for the presence of acrosin.

\footnotetext{
*Correspondence.

${ }^{\dagger}$ Present address: Institut für Reproduktionsmedizin, Bünteweg 15, 3000 Hannover 71, Germany.

Received 25 May 1993.
}

In the present report, we provide evidence for the presence of proacrosin in both fluid and epithelial cells of the seminal vesicles of boars.

\section{Materials and Methods}

Preparation of tissues and fluids

Blood serum and secretions from boar seminal vesicles, testes, prostate and cauda epididymides, and pig follicular fluid were obtained from slaughtered animals. The testis connected with the epididymis was separated from the connective tissue and washed with saline. The epididymis was cut from the testis, and testis secretion collected by puncturing the rete testis duct with a glass capillary. The epididymis was filled with air by means of an injection syringe and a needle inserted into the vas deferens. By inserting another needle into the cauda epididymis duct a mixture of spermatozoa and fluid was obtained. The prostate and seminal vesicles separated from the connective tissue were cut away from the urethra, and the secretions were collected by applying pressure. After centrifuging the secretions for $15 \mathrm{~min}$ at $3500 \mathrm{~g}$, the supernatants were frozen and stored at $-70^{\circ} \mathrm{C}$. The tissues from reproductive and other organs were obtained from slaughtered animals, frozen in liquid nitrogen and stored at $-70^{\circ} \mathrm{C}$. The isolation of boar $\alpha$ - and $\beta$-acrosin forms was as described by Železná and Čechová (1982) and Čechová et al. (1988). 


\section{Materials}

Peroxidase-conjugated rabbit anti-mouse IgG was obtained from Sigma (St Louis, MO); goat anti-rabbit IgG coupled to peroxidase and pig either anti-mouse or anti-rabbit globulin coupled with fluorescein isothiocyanate (FITC) were from Sevac (Prague). Sephadex G-75 and reversed-phase column were from Pharmacia (Uppsala). Micro-enzyme-linked immunosorbent assay (ELISA) plates were from Dynatech (Denkendorf), ultrafiltration membrane YM 10 from Amicon (Lexington, MA). All the other reagents were purchased from standard commercial sources. Rabbit antiserum to acrosin was prepared by immunizing female rabbits, each with an intracutaneous injection of $\mathrm{I} \mathrm{mg} \alpha$-acrosin (Železná and Čechová, 1982) dissolved in $0.1 \mathrm{ml}$ saline mixed with complete Freund's adjuvant. Two months later, rabbits were injected with $200 \mu \mathrm{g}$ of the antigen in complete Freund's adjuvant. Two weeks after the last injection, blood samples were collected from the ear vein. Antiserum was heat inactivated for $30 \mathrm{~min}$ at $56^{\circ} \mathrm{C}$. The titre of antibodies checked with $10 \mu \mathrm{g}$ of antigen by ELISA was 1:50000. Preparation and characterization of the monoclonal antibody (MO.AKR1) were as described by Pěknicová $e t$ al. (1986) and Tesař́k et al. (1988). The mouse monoclonal antibody and rabbit serum against acrosin did not react with pig trypsin, chymotrypsin, plasmin or kallikrein.

\section{Enzyme-linked immunosorbent assay}

The acrosin concentration in blood serum, seminal plasma and reproductive tract fluids was assayed by priming wells in microELISA plates with antigens ( $1 \mu \mathrm{g}$ per well) in phosphatebuffered saline (PBS) at $4^{\circ} \mathrm{C}$. After extensive washing (PBS, $1 \%$ BSA, $0.05 \%$ Tween 20 ), anti-acrosin rabbit serum (serial dilutions in PBS-Tween) was added to each well and the plates were incubated at $22^{\circ} \mathrm{C}$ for $1 \mathrm{~h}$. After thorough washing, the anti-acrosin antibodies were reacted at $37^{\circ} \mathrm{C}$ for $1 \mathrm{~h}$ with $100 \mu \mathrm{l}$ of $1 ; 1000(\mathrm{v}: \mathrm{v})$ goat anti-rabbit globulin coupled to peroxidase, washed again and the bound peroxidase activity was detected using o-phenylene diamine and hydrogen peroxide as substrate. The absorbance was determined at $495 \mathrm{~nm}$ using an RM ELISA reader (Dynatech AG, Branch Germany, Denkendorf). For detection of the antigen in column effluent the wells in microELISA plates were primed overnight at $4^{\circ} \mathrm{C}$ with either $50 \mu \mathrm{l}$ column effluent (after Sephadex G-75) and $50 \mu \mathrm{l}$ coating buffer $\left(0.05\right.$ mol sodium carbonate $1^{-1}$ plus $0.5 \mathrm{~mol}$ sodium hydrogen carbonate $1^{-1}, \mathrm{pH} 9.6$ ), or $25 \mu \mathrm{l}$ column effluent (reversed-phase chromatography), $25 \mu \mathrm{l} \mathrm{Imol}$ Tris $\mathrm{l}^{-1}$, and $50 \mu \mathrm{l}$ coating buffer. After extensive washing (PBS, $0.5 \%$ BSA, $0.05 \%$ Tween 20), $100 \mu \mathrm{l}$ of antibody preparation diluted either 1:1000 (monoclonal) or 1:10 000 (polyclonal) was added to each well and the plates were incubated at $37^{\circ} \mathrm{C}$ for $2 \mathrm{~h}$, as described above.

\section{Fluorescence labelling assays}

An indirect immunofluorescence technique was applied to detect the acrosin in slices ( $3 \mu \mathrm{m}$ thick) of frozen pig tissues of vesicular gland, caput, corpus and cauda of epididymides, testes, prostate, urethra, bulbourethral gland, liver, kidney, heart, spleen, pancreas, intestines, lungs, lymphatic gland and muscle. The tissue sections were obtained from seven animals. At least four sections of any tissue sample per animal were evaluated. Frozen tissue sections were incubated with a drop of antiserum (either mouse monoclonal or rabbit polyclonal) diluted 1:30 (v:v) or 1:60 (v:v) respectively with PBS for $1 \mathrm{~h}$ at $22^{\circ} \mathrm{C}$. After washing $(0.2 \%$ BSA in PBS), pig, either antimouse or anti-rabbit, globulin coupled with fluorescein isothiocyanate (FITC) diluted I:I5 (v:v) and preabsorbed with tissue homogenate was used as the second incubation medium. The culture supernatant of parental Sp 2/0 Ag14 myeloma cells and normal mouse serum served as controls for the monoclonal antibody. Both normal rabbit serum and antiserum to $\alpha$-acrosin preabsorbed with the same compound $\left(4 \mathrm{mg} \mathrm{ml}^{-1}\right)$ were used as controls for rabbit anti-acrosin serum. The slides were observed with an Orthoplan-Leitz microscope (Westlar) equipped with a halogen-quartz lamp using an FITC interference filter.

\section{Purification of protease from seminal vesicle fluid}

Seminal vesicle fluid ( $135 \mathrm{mg}$ of proteins in $7.5 \mathrm{ml}$ ) was fractionated at $4^{\circ} \mathrm{C}$ on a Sephadex G-75 column $(2.6 \mathrm{~cm} \times 68 \mathrm{~cm})$ equilibrated with $1 \mathrm{mmol}$ hydrochloric acid $\mathrm{I}^{-1}$ (flow rate $0.18 \mathrm{ml} \mathrm{min}{ }^{-1}$. Fractions, $3.6 \mathrm{ml}$, were screened for absorbance at $280 \mathrm{~nm}$, presence of amidase activity and acrosin inhibitors and for immunoreactivity (see below). Both high and low molecular mass antigen-containing fractions were separately pooled, concentrated with an ultrafiltration membrane to $30 \%$ of the volume, and used for electrophoretic studies, or further purified by reversed-phase chromatography. The material $(2 \mathrm{ml})$ was applied to a $1 \mathrm{~cm} \times 10 \mathrm{~cm}$ ProRPC $15 \mu \mathrm{m} \mathrm{HR} 10 / 10$ column and eluted with a linear gradient of $0-60 \%(\mathrm{v} / \mathrm{v})$ acetonitrile in $0.1 \%$ trifluoroacetic acid at a flow rate of $3 \mathrm{ml} \mathrm{min}{ }^{-1}$ for $65 \mathrm{~min}$, using the fast-protein liquid chromatography (FPLC) system. Proteins were detected by absorbance at $280 \mathrm{~nm}$. The fractions ( $1.5 \mathrm{ml}$ each) were screened for activable zymogen, for immunoreactivity by ELISA.

\section{Zymogen activation, enzyme and acrosin inhibitor assays}

Zymogens were converted to active enzymes by incubation at $25^{\circ} \mathrm{C}$ in $\mathrm{pH} 7.8$, and the resulting enzymatic activities were measured at $25^{\circ} \mathrm{C}$ in terms of hydrolysis of the chromogenic substrate $\mathrm{N}$ - $\alpha$-benzoyl-DL-arginine nitroanilide. After gel filtration, $0.5 \mathrm{ml}$ of each fraction was diluted with $2.0 \mathrm{ml}$ of $0.2 \mathrm{~mol}$ Tris-chloride $1^{-1}, \mathrm{pH} 7.8$, with $0.025 \mathrm{~mol}$ calcium chloride $\mathrm{l}^{-1}$, and $500 \mathrm{ng}$ trypsin was added as activator. After incubation for $10 \mathrm{~min}, 1 \mathrm{mg} N$ - $\alpha$-benzoyl-DL-arginine nitroanilide in $0.1 \mathrm{ml}$ dimethylformamide was added: the reaction was stopped after $15 \mathrm{~min}$ with $0.5 \mathrm{ml}$ of $30 \%(\mathrm{v} / \mathrm{v})$ acetic acid, and absorbance was measured at $405 \mathrm{~nm}$ against a blank (with buffer instead of fraction solution). For detection of trypsin-like activity after reversed-phase chromatography, the assay was performed in the absence of calcium chloride and trypsin; $0.2 \mathrm{ml}$ of each fraction was tested. The same procedure was 
(a)

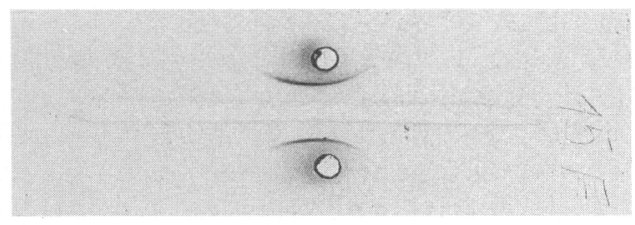

A

$\mathbf{B}$

(b)

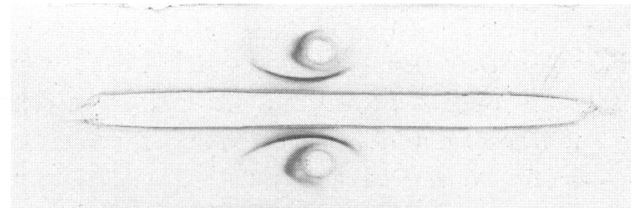

A

B

Fig. 1. Immunoelectrophoretic pattern of the reaction of antisera to $\alpha$-acrosin with acrosin and seminal vesicle fluid of boars. (a) $a$-acrosin $(A-0.5 \%$; $B-0.25 \%$ ); (b) seminal vesicle fluid $(A-0.5 \%$; $-1.0 \%$ ).

used to estimate preformed enzymes, except that the substrate was added before the zymogen. Determination of acrosin inhibitors was based on the assay of the residual amidase activity of acrosin after incubation for 10 min with inhibitor (Železná and Čechová, 1982). The protein concentration was estimated spectrophotometrically at $280 \mathrm{~nm}$, assuming that $1 \mathrm{mg}$ protein $\mathrm{ml}^{-1}$ exhibits an absorbance of 1.0 at $280 \mathrm{~nm}$ in a $1 \mathrm{~cm}$ light path.

\section{Gel electrophoresis and protein and enzyme detection}

For protease zymographic detection, 10\% sodium dodecyl sulfate-polyacrylamide gel electrophoresis (SDS-PAGE) (slab gels $1 \mathrm{~mm}$ ) containing $0.08 \%$ casein was used (Čechová et al., 1990). The samples were prepared in Laemmli sample buffer (Laemmli, 1970) without reduction. After SDS-PAGE, the gels were washed for $1 \mathrm{~h}$ at room temperature in $2.5 \%(\mathrm{v} / \mathrm{v})$ Triton $X-100$ in water and then three times with distilled water. After incubation in $100 \mathrm{mmol}$ glycine $1^{-1}$, adjusted with sodium hydroxide to $\mathrm{pH} 8.3$, at $37^{\circ} \mathrm{C}$ for $2 \mathrm{~h}$, the gels were stained for $\mathrm{Ih}$ in $0.1 \%$ Amido Black $10 \mathrm{~B}$. Proteolytic digestion was detected by observing clear zones of casein hydrolysis. Proacrosin, $\beta$-acrosin, plasmin and chymotrypsin were used as enzyme standards.

\section{Other methods}

Immunoelectrophoresis was performed according to Williams (1971). Zona-binding activity was tested by means of the solid phase zona-binding assay as described by Töpfer-Petersen and Henschen (1987). Sperm immobilization test was performed according to Isojima et al. (1987).

\section{Results}

\section{Preparation and characterization of antisera}

A rabbit antiserum against $\alpha$-acrosin was obtained by immunizing rabbits with a highly purified protein sample. A single precipitation line was seen when the antibody was tested
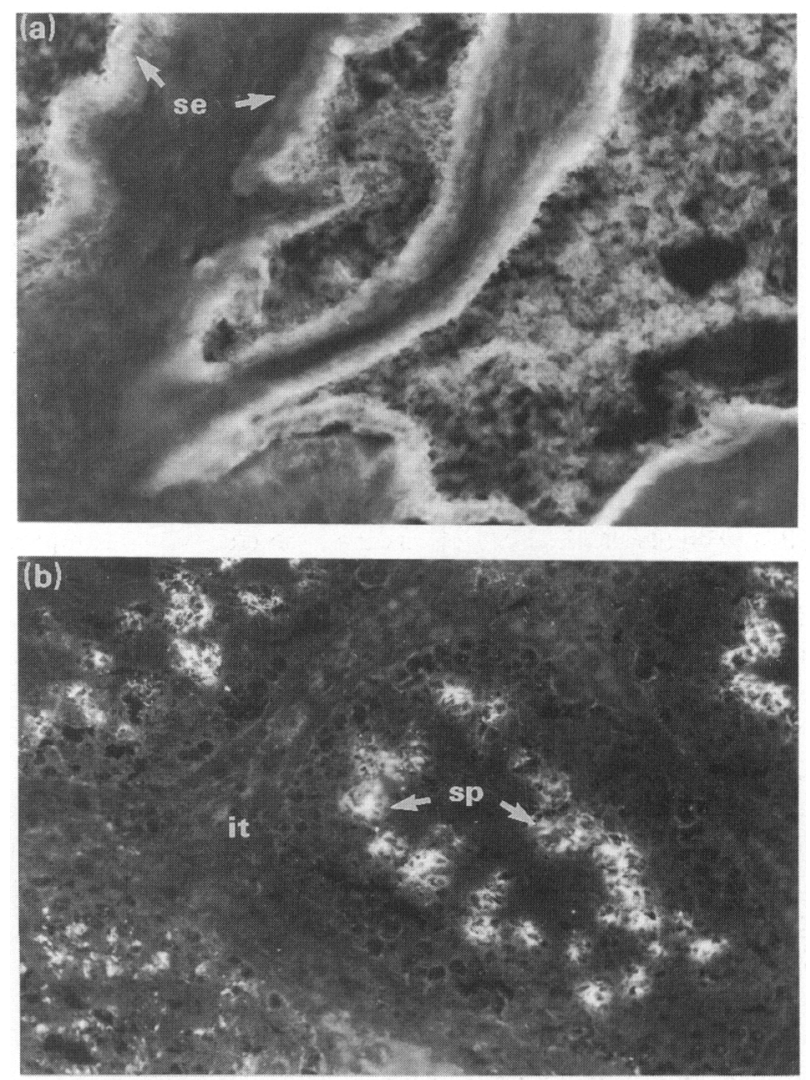

Fig. 2. Reactivity of anti-acrosin monoclonal antibody to antigen in frozen tissue sections detected by an indirect immunofluorescence assay. (a) Seminal vesicle tissue $(\times 240)$. Strong immunoreactivity was localized in secretory epithelium (se). (b) Testicular tissue $(\times 240)$. The positive reaction of antibody was evident in all seminiferous tubules of the testis at the level of spermatids (sp) in tubular lumen. No fluorescence was seen in interstitial tissue (it). (Controls exposed to the action of normal mouse serum and anti-mouse globulin labelled with fluorescein isothiocyanate were negative.)

against the antigen, i.e. acrosin (Fig. Ia). The same precipitation line was observed when the antibody was tested against seminal vesicle fluid (Fig. 1b), but when a high concentration of seminal vesicle fluid was used a second faint band was also found. The antigen did not react with any of the other fluids tested.

In ELISA, the antiserum titre in the reaction with $10 \mu \mathrm{g}$ of the $\alpha$-acrosin was 1:50 000, and with proacrosin sample was 1:200 000. The sperm immobilization test gave negative results.

\section{Localization of antigen}

In ELISA, both monoclonal and polyclonal antibodies against acrosin reacted with seminal vesicle fluid. The titre of polyclonal antibodies was 1:25 000. The reactions with blood serum and the other fluids tested (epididymal, testicular, prostatic and follicular) were negative.

After application of either mouse monoclonal or rabbit polyclonal antibodies against acrosin to tissue sections, strong fluorescence of the secretory epithelium in boar seminal vesicle 
A

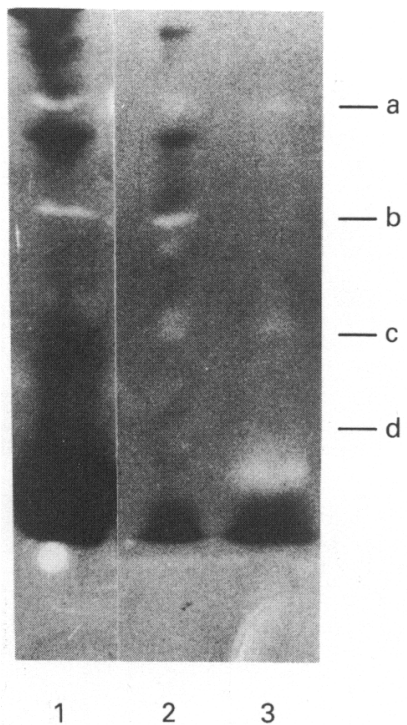

B

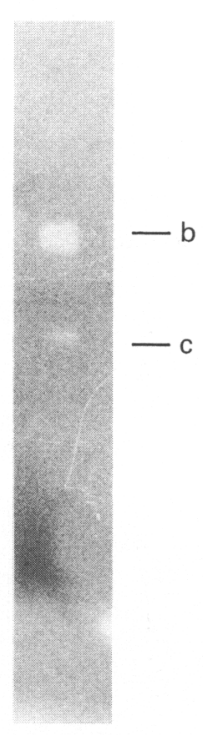

Fig. 3. Patterns of zymograph SDS polyacrylamide gel electrophoresis of protease-containing material. Samples were subjected to electrophoresis in SDS polyacrylamide gels containing casein and then analysed for protease digestion. Caseinolytic activity appeared as a clear band on the dark background. Electrophoretic mobility of (a) plasmin, (b) proacrosin, (c) $\beta$-acrosin and (d) chymotrypsin are indicated. A: Lane (1) fluid of boar seminal vesicle $(100 \mu \mathrm{g})$; lane (2) high molecular mass antigen fraction after gel filtration $(50 \mu \mathrm{g})$; lane (3) low molecular mass antigen fraction after gel filtration $(200 \mu \mathrm{g})$. B: Pooled fractions contained proacrosin after reversed-phase column chromatography $(2 \mu \mathrm{g})$.

tissue was detected (Fig. 2a). The control with a normal serum was negative. The testicular tissue (Fig. 2b) was negative, but a strong fluorescence of germ cells in seminiferous tubules was found. No fluorescence was observed when the antiserum was applied to pig erythrocytes, lymphocytes or any other tissue tested (prostate, epididymides, bulbourethral gland, liver, pancreas, heart, spleen, lungs, intestine, kidney and muscle).

\section{Purification of antigen from seminal vesicle fluid}

Ultrasensitive protease detection zymography was used to follow the presence of proteases in seminal vesicle fluid. Two digestion bands were observed (Fig. 3), one with relative molecular mass similar to that of plasmin, and the other with relative molecular mass similar to that of proacrosin. Gel filtration on a Sephadex G-75 column was used as the first step of purification. Both polyclonal and monoclonal antibodies to boar acrosin were tested for immunoreactivity in column effluent. On the elution profile (Fig. 4), two peaks of immunological activity to anti-acrosin serum were visible. No difference was found when either monoclonal or polyclonal antibodies were used in microELISA tests. The higher molecular mass antigen emerged from the column in the same effluent volume as did proacrosin. The enzyme eluted as zymogen which had to be activated with a small amount of trypsin. The ELISA maximum corresponded very well to the level of

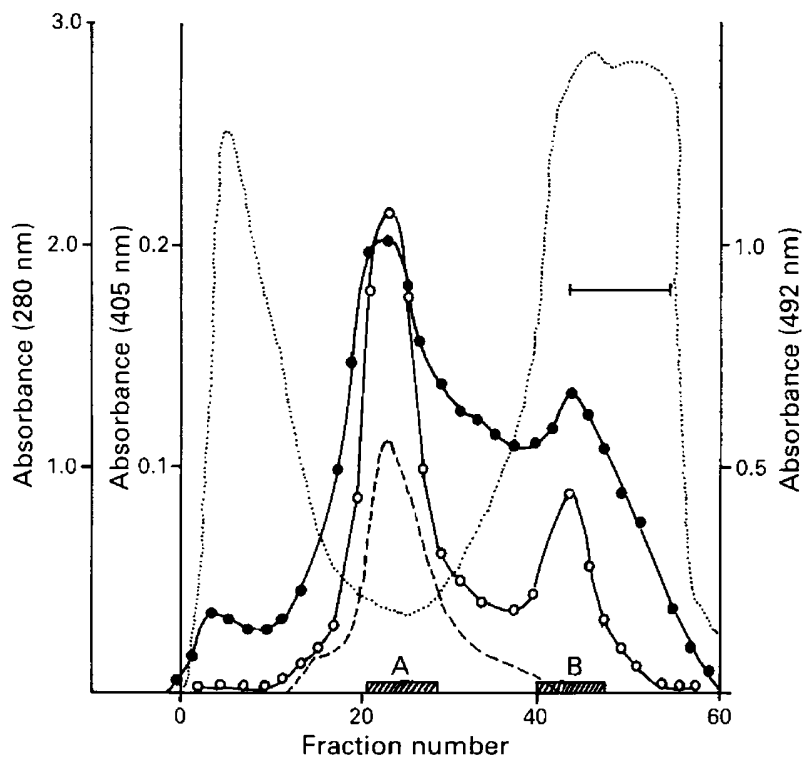

Fig. 4. Gel filtration of boar seminal vesicle fluid on Sephadex G-75. $(\cdots)$ absorbance at $280 \mathrm{~nm}$; $(--)$ amidase activity after activation with trypsin; (O-O) enzyme-linked immunosorbent assay (ELISA) reaction with monocional antibody; (- -1 ) ELISA reaction with rabbit polyclonal antibodies expressed as absorbance at $492 \mathrm{~nm}$; ( ) fractions containing trypsin inhibitor activity; ( שTIS ) pooled fractions A and B.

amidase activity obtained after activation. The lower molecular mass antigen was eluted after gel filtration together with proteinaceous acrosin inhibitors present in seminal vesicle fluid. The amidase activity in the low molecular mass substance could not be detected even in the presence of trypsin. The fractions corresponding to both antigens were pooled (Fig. 4). Pooled fractions A and B contained proteolytic activity, as evidenced by a positive reaction using ultrasensitive protease detection zymography (Fig. 3). Caseinolytic activity (clear area) of the major high molecular mass fraction $\mathrm{A}$ occurred in the proacrosin region. The proteolytic activity of the minor low molecular mass fraction $B$ was apparent in a region with relative molecular mass lower than $25 \mathrm{kDa}$ (chymotrypsin). The elution profile obtained from reversed-phase chromatography of the high molecular mass fraction $A$ is shown (Fig. 5a). The latent protease activity (zymogen) was eluted with $40 \%$ acetonitrile. The zymogen was autoactivated at $\mathrm{pH} 8.0$ with sigmoidal kinetics (Čechová et al., 1988). No preformed amidase activity could be detected before autoactivation. An acrosin inhibitor eluted at $37 \%$ acetonitrile (Fig. 5a). The maximum of microELISA and zona-binding assays corresponded well to the maximum of amidase activity obtained after activation. The elution profile obtained from reversedphase chromatography of pooled low molecular mass antigencontaining fraction B from Sephadex G-75 is shown (Fig. 5b). Amidase activity eluted at $40 \%$ acetonitrile and could be detected without autoactivation. The maximum of amidase activity and microELISA tests was in excellent agreement. Zona-binding test and zymographic detection of this sample were done and negative results were obtained. A large amount of acrosin inhibitor was eluted with $24 \%$ acetonitrile. 

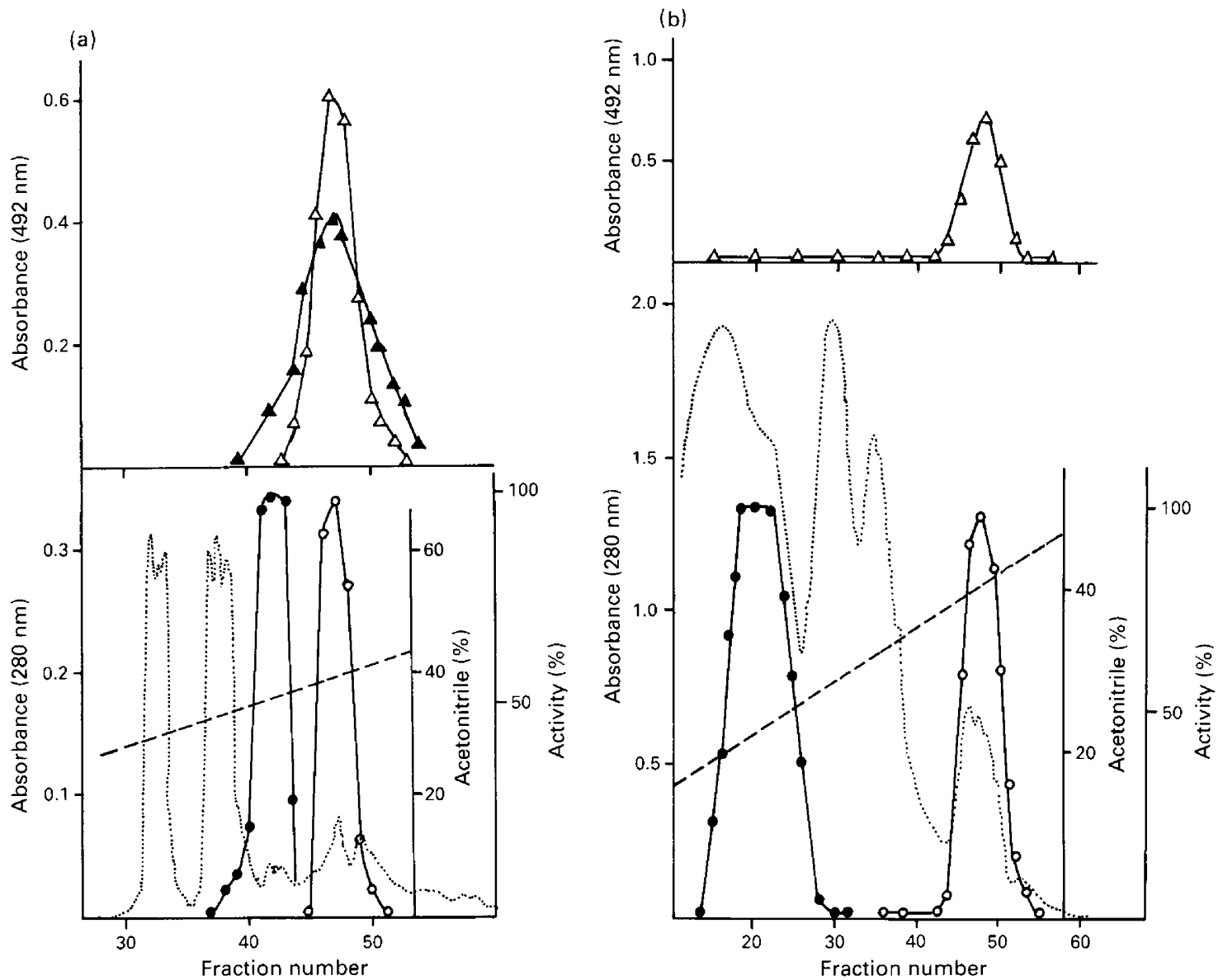

Fig. 5. Elution patterns of chromatography of the crude proacrosin/acrosin fractions eluted from Sephadex G-75 column on a reversed-phase column in $0.1 \%$ trifluoroacetic acid and $0-60 \%$ acetonitrile. (a) Chromatography of the $\mathrm{A}$ fraction. (b) Chromatography of the B fraction. ( ...) Absorbance at $280 \mathrm{~nm} ;(---)$ percentage of acetonitrile; $(\mathrm{O}-\mathrm{O})$ amidase activity (in (a) after autoactivation, in (b) without autoactivation), and (- acrosin inhibitor activity indicated as percentage of maximum activity; $(\triangle-\triangle)$ microELISA activity and $(\boldsymbol{\Delta}-\mathbf{\Delta})$ zona-binding activity expressed as absorbance at $492 \mathrm{~nm}$.

\section{Discussion}

The trypsin-like serine protease, acrosin, appears to have a specific function at the molecular level of fertilization, presumably by facilitating the penetration of spermatozoa through the zona pellucida of the ovum (for review see Hedrick et al., 1988) or in the acrosome reaction (Tesarík et al., 1990). Acrosin is considered to be highly specific for mammalian spermatozoa. There is no evidence indicating that proacrosin or acrosin is present in any other body cell or fluid, but the fluid of seminal vesicles had not been tested. Using sensitive zymographic detection after SDS-PAGE of boar seminal vesicle fluid, we observed a faint zone of proteolysis that appeared at a position corresponding to that of proacrosin. To characterize that protease, we partially purified the enzyme using the method recently described for boar proacrosin or sperminogen isolation (Čechová et al., 1988, 1990). The elution pattern of a Sephadex G-75 column demonstrated that in seminal vesicle fluid of the boar two compounds crossreacted with antibodies to acrosin and differed in their molecular masses. The faint amidase activity after activation with trypsin could be determined only in the high molecular mass material. Both materials, however, showed proteolytic activity to casein on zymograph electrophoresis. After the reversed-phase chromatography of the high molecular mass material, a zymogen of trypsin-like protease emerged from the column in $40 \%$ acetonitrile, as did proacrosin (Cechová et al., 1988). The zymogen was separated from acrosin inhibitor. The presence of that inhibitor in the acrosinlike fraction eluted from Sephadex G-75 could account for the fact that the zymogen did not autoactivate. Inhibitors of acrosin prevent the activation of proacrosin (for review see Parrish and Polakoski, 1979). The results indicated that the fluid of boar seminal vesicles expressed a zymogen that was electrophoretically and antigenically indistinguishable from proacrosin. We do not have amino acid sequence evidence that the zymogen is proacrosin, but the strong similarities in molecular mass, immunological and chemical properties, zymogen activation, and enzymatic activity, with proacrosin and acrosin support the contention that the zymogen detected in seminal vesicle fluid and tissue is proacrosin. The information about the presence of proacrosin in boar seminal vesicle fluid is new and it is not consistent with a view of high 
specificity of the acrosin for sperm cells only. It has not been detected in any other cell or fluid in the mammalian body. The results presented here, using immunofluorescence, indicate that proacrosin-like antigen is probably synthesized by seminal vesicle epithelia. It is difficult to determine whether the same structural gene is expressed both in spermatids and in epithelial cells of seminal vesicles or whether two different structural genes are expressed in different tissues. A protease separated from seminal acrosin inhibitors was obtained after reversedphase chromatography of the low molecular mass immunoactive fraction. The existence of the low molecular mass acrosin-like antigen in boar seminal fluid is unexpected. The protease was eluted from the column in $40 \%$ acetonitrile as was the acrosin, but the explanation that the low molecular mass acrosin is an artefact of proacrosin autodigestion does not seem satisfactory. The autodigestion of the proacrosin proceeds in a stepwise fashion (Parrish and Polakoski, 1979) and passes through a very stable $35 \mathrm{kDa}$ product (Železná and Čechová, 1982). We could not detect the $35 \mathrm{kDa}$ acrosin in seminal vesicle fluids of any of the six boars tested. Furthermore, the autodigestive $24 \mathrm{kDa}$ product (Parrish and Polakoski, 1979) has never been observed under physiological conditions (Moos et al., 1991). We conclude that the low molecular mass acrosin-like protease in seminal vesicle fluid has a special function. The low molecular mass antigen was detected in the seminal fluids of all six boars tested (unpublished observations).

Proteases serve as biological regulators of a variety of physiological processes. Seminal plasma contains a variety of proteases, together with a number of protease inhibitors and activators (for review see Morton, 1977). At present, the physiological roles of most of these proteases are not known. It has been suggested that limited proteolysis may play a role in the apparent loss or modifications of sperm surface molecules that occur during epididymal maturation and capacitation. The action of seminal plasma proteases on bulk proteins in seminal plasma results in the formation of vasoactive small polypeptides, and in maturation of a peptide hormone. Saling et al. (1981) proposed that an enzyme of tryptic specificity is involved in the binding of mouse spermatozoa to zona pellucida and Meizel and Lui (1976) and Meizel (1985) proposed that it is involved in the acrosome reaction. It is not known which gland produces seminal plasma proteases. In prostatic fluids of some species, proteases with kallikrein-like specificities were detected (Lazure et al., 1984; Lilja and Laurel, 1985) and their physiological function was determined (Lilja and Laurel, 1985). Data about proteases in secretions of seminal vesicles are even more scarce. In the human seminal vesicle, a zymogen of a serine protease has been demonstrated, the activation of which was inhibited by an inhibitor of both urokinase and protein $C$ (Laurell et al., 1992). It is possible that the zymogen might be an extracellular proacrosin, similar to that found in seminal vesicles of boars. The role of acrosin bound to the intraacrosomal membrane in the secondary phase of spermegg binding has been suggested by Töpfer-Petersen and Henschen (1987) and Jones and Brown (1987), but the proacrosin-acrosin system present on the surface of the plasma membrane of the sperm head (Tesaŕik et al., 1988, 1990) might also be involved in the primary phase of sperm-egg binding. In the light of the new data we consider that the proacrosin-like antigen detected on the surface of sperm plasma membrane (Tesařik et al., 1988) originated from seminal vesicle fluid rather than from the sperm acrosome, where it had to traverse the barrier of two membranes. The role of acrosin-like protease in seminal vesicle fluid may also be connected with a limited cleavage or solubilization of fibronectins (Planchenault et al., 1991).

\section{References}

Brown CR and Harrison RAP (1978) The activation of proacrosin in spermatozoa from ram, bull, and boar Biochimica et Biophysica Acta 526 202-217

Cechová D, Töpfer-Petersen E and Henschen A (1988) Boar proacrosin is a single-chain molecule which has the $N$-terminus of the acrosin A-chain (light chain) FEBS Letters 241 136-140

Čechová D, Töpfer-Petersen E, Zucker A and Jonáková V (1990) Is sperminogen a modified proacrosin? Isolation, purification and partial characterization of low-molecular-mass boar proacrosin Biological Chemistry Hoppe-Seyler 371 317-323

Flörke S, Phi-van L, Müller-Esterl W, Scheuber H-P and Engel W (1983) Acrosin in the spermiohistogenesis of mammals Differentiation 24 250-256

Hedrick JR, Urch UA and Hardy DM (1988) The structure-function properties of the sperm enzyme acrosin. In Enzymes in Agricultural Biotechnology (ACS Symposium Series), pp 1-11 Eds S Shoemaker, P Sonnet and J Whitaker. ACS Books, Washington

Isojima S, Kameda K, Tsuji Y, Shigeta M, Ikeda Y and Koyama K (1987) Establishment and characterization of a human hybridoma secreting monoclonal antibody with high titers of sperm immobilizing and agglutinating activities against human seminal plasma Joumal of Reproductive Immunology $1067-78$

Jones R and Brown CR (1987) Identification of a zona-binding protein from boar spermatozoa as proacrosin Experimental Cell Research 171 503-508

Klemm U, Müller-Esterl W and Engel W (1991) Acrosin, the peculiar spermspecific serine protease Human Genetics 87 635-641

Laemmli UK (1970) Cleavage of structural proteins during the assembly of the head of bacteriophage T4 Nature 277 680-685

Laurell M, Christensson A, Abrahamsson P-A, Stenflo J and Lilja H (1992) Protein $C$ inhibitor in human body fluids. Seminal plasma is rich in inhibitor antigen deriving from cells throughout the male reproductive system Journal for Clinical Investigation 89 1094-1101

Lazure C, Leduc R, Seidach NG, Chrétien M, Dubé JY, Chapdelaine P, Frenette G, Paquin R and Tremblay RR (1984) The major androgen-dependent protease in dog prostate belongs to the kallikrein family: confirmation by partial amino acid sequencing FEBS Letters $175 \quad$ I-7

Lilja $\mathrm{H}$ and Laurell CB (1985) The predominant protein in human seminal coagulate Scandinavian Journal of Clinical Laboratory Investigation $\mathbf{4 5}$ 635-641

Meizel S (1985) Molecules that initiate or help stimulate the acrosome reaction by their interaction with the mammalian sperm surface American Journal of Anatomy 174 285-302

Meizel S and Lui CW (1976) Evidence for the role of a trypsin-like enzyme in the hamster sperm acrosome reaction Journal of Experimental Zoology 195 137-144

Moos J, Tesarik J, Leca G and Pěknicová J (1991) Mechanism of maturation and nature of carbohydrate chains of boar sperm acrosin FEBS Letters 294 $27-30$

Morton DB (1977) The occurrence and function of proteolytic enzymes in the reproductive tract of mammals. In Proteinases in Mammalian Cells and Tissues, pp 445-500 Ed. AJ Barrett. Elsevier/North-Holland Biomedical Press, Amsterdam

Nayernia K, Burkhardt E, Beimesche S, Keime S and Engel W (1992) Germ cell-specific expression of a proacrosin-CAT fusion gene in transgenic mouse testis Molecular Reproduction and Development 31 241-248

Parrish RF and Polakoski KL (1979) Mammalian sperm proacrosin-acrosin system International Journal of Biochemistry 10 391-395

Pěknicová J, Čapková J, Čechová D and Šulcová B (1986) Preparation and characterization of a monoclonal antibody against boar acrosin Folia biologica 32 282-285

Planchenault T, Cechová D and Keil-Dlouha V (1991) Matrix degrading properties of sperm serine proteinase, acrosin FEBS Letters 294 279-281 
Saling PM (1981) Involvement of trypsin-like activity in binding of mouse spermatozoa to zonae pellucidae Proceedings of the National Academy of Sciences USA 78 6231-6235

Tesařik J, Drahorád J and Pěknicová J (1988) Subcellular immunochemical localization of acrosin in human spermatozoa during the acrosome reaction and zona pellucida penetration Fertility and Sterility 59 133-14 I

Tesařik J, Drahorad J, Testart J and Mendoza C (1990) Acrosin activation follows its surface exposure and precedes membrane fusion in human sperm acrosome reaction Development $110391-400$
Töpfer-Petersen E and Henschen A (1987) Acrosin shows zona and fucose binding, novel properties for serine proteinase FEBS Letters 226 38-42

Williams CA (1971) Immunoelectrophoretic analysis. In Methods in Immunology and Immunochemistry III, pp 234-240 Eds CA Williams and MW Chase. Academic Press, New York

Železná B and Cechová D (1982) Boar acrosin: isolation of two active forms from boar ejaculated sperm Hoppe Seyler's Zeitschrift für Physiologische Chemie $363757-766$ 